International Journal of Engineering \& Technology, $7(4.33)(2018) 138-143$
International Journal of Engineering \& Technology
SPC
Website: www.sciencepubco.com/index.php/IJET
Research paper

\title{
Wayfinding for Pedestrians: Overview of the Role of Sidewalk Design
}

\author{
Widi Lesmana $^{1 *}$, Retna Hidayah ${ }^{2}$, Mochamad Bruri Triyono $^{3}$, Asnul Dahar Minghat ${ }^{4}$, Siti Salina Mustakim ${ }^{5}$ \\ ${ }^{I}$ Technology and Vocational Education, Pascasarjana, Yogyakarta State University, Indonesia \\ ${ }^{2}$ Civil Engineering and Planning Education, Faculty of Engineering, Yogyakarta State University, Indonesia \\ ${ }^{3}$ Faculty of Engineering, Yogyakarta State University, Indonesia \\ ${ }^{4}$ Razak Faculty of Technology and Informatics, Univesiti Teknologi Malaysia, Malaysia \\ ${ }^{5}$ Faculty of Educational Studies, Univesiti Putra Malaysia, Malaysia \\ *Corresponding author E-mail: widilesmana19.2017@ student.uny.ac.id
}

\begin{abstract}
The primary aim of this study was to describe the pattern of pedestrian movement and the main cause of students' selection in choosing those particular route. A qualitative research method was utilized for the purpose of data collection via an interview data retrieval technique. Findings were transcribed, coded, and analyzed manually. Findings indicated that students' difficulties in finding Rectorate Building were $27.5 \%$. There were $75 \%$ of students who receive information for directions from the results of questioning with other students in the campus, while those who only read the guide map were only $25 \%$. There were $55 \%$ of students choose route based on the closest distance, while comfort factor is $11.25 \%$. Only $71.25 \%$ students use sidewalks, while those who do not always use pavements were $28.75 \%$. Viewed from gender, it was indicated that difficulties in finding Rectorate Building was $44.7 \%$ from male and $38.1 \%$ from female. $60.5 \%$ of male and $73.8 \%$ of female prefer to ask verbally to find travel information, while $39.5 \%$ of male and $26.2 \%$ of female would read the guide map. $59.5 \%$ female and $31.5 \%$ of male prefer the shortest route. The users of sidewalks were $52.6 \%$ male and $69.2 \%$ female. This study contributes to the implementation and integration of sustainable green campus in Indonesia.
\end{abstract}

Keywords: Wayfinding for Pedestrian; Sidewalk Design; Choose the Route.

\section{Introduction}

Perfect plan is a planning that can be implemented, beneficial, and useful to the nation. Pertaining to building development towards its usability among the citizen, one of the building design parameters is the ease of use of the building, and its accessibility. The ease of use is mainly supported by the ease of finding ways (wayfinding) and the ease of the user for buildingoriented (spatial orientation) [1]. Yogyakarta State University (YSU) provides spacious, wide and comfortable path for road users particularly among students in the campus. Due to its wide area and labyrinth accessibility among faculties, buildings designed in the campus are congested, and provide confusion to new registered student of being accessed to their faculties, or in fact, to other buildings. Rectorate Building is a strategic location that has been designated by many students. Students from each faculty have considerations in terms of using the service and facilities in the Rectorate Building. Facts on the ground indicated that the presence of facilities such as a signpost-building name on every street is very important.

The existence of a sidewalk equipped with a roof covering considered as a friendly user, since it is applied to weather changes, and provided with; each building is a sidewalk that connected closely to one another. A preliminary investigation via observations indicated that only few pedestrians using the sidewalk as an access to the location of interest. In order for pedestrians to utilize the campus facilities, they are required to share in com- mon vehicles. The physical quality of the pedestrian element in the university can be utilized by pedestrians as a supporting ease of wayfinding in the campus. Therefore, in these circumstances, an investigation on patterns of student movement against the route used to go to the Rector Building along with the reason for choosing that route is deemed crucial. Hence, the primary aim of this study is to describe the route used by the students of the faculty as a starting point to get to the Rectorate Building.

\section{Wayfinding, Sidewalk Design, and Its Ac- cessibility}

The design of the physical environment plays a major role in supporting the wayfinding abilities of people with dementia [2]. Meanwhile, according to [3], pedestrians possess no or only parts of information about their position relative to final exits and possible routes leading to them. To get a more realistic description, a new wayfinding model for pedestrian dynamics is needed. The model defines for every pedestrian as an individual knowledge representation implying inaccuracies and uncertainties. Environmental legibility and individual differences impact on wayfinding performance and the development of spatial awareness. In [4] reveals that people have great difficulties in gathering wayfinding information to move independently in an unfamiliar environment so guide paths based on the luminance contrast between a strip and surrounding surfaces can be an 
effective device for mitigating these difficulties, but information provided by the scientific literature on guide paths cannot be usefully applied to the naturally coloured paving materials most commonly found in pedestrian urban spaces [5].

Several factors need to be considered in analyzing the characteristics of travel patterns, among others: (a) the number of city dwellers, (b) defeat, (c) the structure of the city, (d) the structure of the household, (e) the level of public transport services as well as (f) the individual attributes [6]. According to [7], the accessibility is a matter of time and it also depends on the attractiveness and identity of the trip. If somewhere adjacent to other places, it is said accessibility between these two places are higher. In addition to the distance and the time, cost is also an indicator of accessibility. Cost is a combination of time and costs as a measure of transport links [8].

Factors affecting performance pedestrian path is a function, mobility, facilities, accessibility, safety, hygiene and beauty [9] Hiking accessibility for disability, according to [10], the principle of accessibility to health facilities is very simple with disabilities, accessibility has said that everyone can reach and enter a building area of environment can then use all the facilities in it without getting into an object the mercy of others.

Pedestrians are people doing activities on foot and is one element of road users [11]. To analyze the behavior of pedestrians in the reverse flow, where someone tried to approach others in the same direction to avoid conflicts with hikers from the opposite direction, the behavior has a significant influence on the phenomenon of formation of lines and efficiency of traffic [12]. Characteristic of pedestrians according to [13] includes the volume of pedestrians, crossing speed, and density. Physical and Non Physical aspects are fundamental elements that support a sense of comfort in using the pedestrian lane road pavement [14] In [15] has told that in building a pedestrian crossing facilities, one should consider the characteristics and behavior of the road users, as well as taking into account their elements of safety that include the arrangement of the pedestrian crossing infrastructure. Sidewalks are the main channels for the walk, which is considered essential to encourage people to become physically active and to create a healthy community [16-17]. In addition, an important factor for improving the transportation associated with viable and sustainable transport [18-20]. The most influential factor to avoid the use of pedestrian walkways is hurdle availability and flow rate, while the security problem is the most influential factor [21]. Gains running such as lower cost and availability for everyone, making it as a form of physical activity most preferred and common [22-26].

Sidewalks are the main channels for the walk, which is considered essential to encourage people to become physically active and to create a healthy community [16-17]. This statement goes in hand with that highlights sidewalks as an important factor for improving the transportation associated with viable and sustainable transport [18-20]. The most influential factor to use of sidewalk are bad elements sidewalk, while the security problem is the most influential factor [21]. Gains running, such as lower time and availability for everyone, making it as a form of physical activity most preferred and common [22-26].

\section{Methodology}

This is a qualitative research method and descriptive in nature. Data collected were from interviews, and the interview questions were adapted and adopted from [27]. A qualitative research method is based on the philosophy of post positivism, used to examine the condition of natural objects [28]. Qualitative research has five characteristics: (1) Do the natural setting, because it is a critical tool is the data directly from the researchers themselves (2) Characteristically descriptive data collected in the form of words or images. (3) More attention to process rather than results. (4) In analyzing the data tends to be inductive, and (5) is essential meaning [29].
Population of the study consist of YSU students who are the pedestrian of their daily routine. These respondents were pedestrians who do not know the ins and outs of the campus environment. Sample size of the study were 80 students from eight faculties and selected randomly of only 10 students from each faculty.

The data analysis technique used is descriptive qualitative analysis of how the data have been collected, and then categorized to be interpreted, with the aim to produce a picture of systematic, factual and accurate information about the phenomenon. The research instrument used in this study were YSU maps, questionnaires and notes. During interview, the researcher describes the pattern of student movement as pedestrian go to Rectorate Building.

\section{Results and Discussion}

\subsection{Findings}

YSU is a public university located in Yogyakarta, Indonesia. Eight faculties involve are the Faculty of Sciences (FIP), Faculty of Engineering (FT), Faculty of Language and Art (FBS), Faculty of Social Sciences (FIS), Faculty of Economics (FE), Faculty of Sport Sciences (FIK), Faculty of Mathematics and science (science) and Graduate Program (PPS). Due to its neighborhood surroundings that consist of many housing areas, it leads to YSU traffic to a congested and crowded to road users. University students share the road with population outsiders to access these roads, considering the road is still in the category of public roads which is not only intended for students. These factors lead to poor pedestrian comfort and safety. Hence, in order to further explain the grouping layout of the environment, the preceding ideas of the map symbols is illustrated in Figure 1:

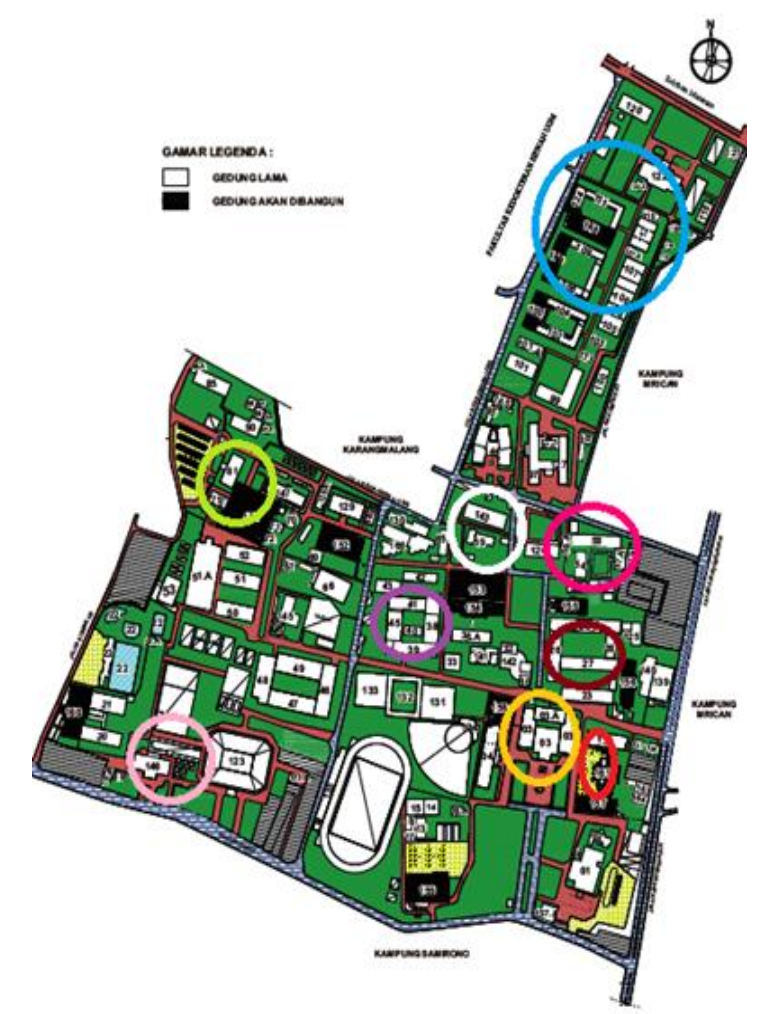

Fig. 1. Site Plan YSU

Information:

1. Blue circle

2. White circle

3. Circles Pink

4. Green circles

5. Brown circle

6. Purple circle
$=$ Faculty of Engineering

$=$ Faculty of Economics

$=$ Faculty of Social Sciences

$=$ Faculty of Language and Art

$=$ Faculty of Education

$=$ Faculty of Mathematics and Science 
7. Red circle = Graduate School

8. Yellow circle $=$ Rectorate Building

\subsection{Results}

\subsubsection{Student Perceptions of each Faculty}

Findings in Table 1 indicated results related to students' perception from each faculty pertaining to determining the route in the university.

Table 1: Student Perception in Determining the Route (P1) Selection of Reasons

\begin{tabular}{|c|c|c|c|c|c|c|c|c|c|}
\hline \multicolumn{10}{|c|}{ Selection of Reasons } \\
\hline P1 & T & E & IS & BS & IP & MP & K & Gs & B \\
\hline Y & 5 & 5 & 4 & 3 & - & 1 & 4 & - & 27.5 \\
\hline N & 5 & 5 & 6 & 7 & 10 & 9 & 6 & 10 & 72.5 \\
\hline
\end{tabular}

$\mathrm{n}=10$ students

Source: Research Data, 2018

\section{Information:}

P1 = Question 1 = Have you ever had trouble on the way to the Rector Building?

$\mathrm{Y} \quad=$ Yes

$\mathrm{N} \quad=\mathrm{No}$

$\mathrm{n} \quad=$ Number of samples of each faculty

$\mathrm{T} \quad=$ Faculty of Engineering

$\mathrm{E} \quad=$ Faculty of Economics

IS $\quad=$ Faculty of Social Science

BS = Faculty of Language and Art

IP = Faculty of Science

MP = Faculty of Mathematics and Science

$\mathrm{K}=$ Faculty of Sport Science

Gs = Graduate School

B $\quad=$ Weight $=($ Real Score: Score Ideal $) * 100 \%$

Table 2: Student Perception in Determining the Route (P2)

\begin{tabular}{|c|c|c|c|c|c|c|c|c|c|}
\hline \multicolumn{10}{|c|}{ The selection These reasons } \\
\hline P2 & T & E & IS & BS & IP & MP & K & Gs & B \\
\hline BT & 3 & 5 & 8 & 7 & 10 & 9 & 8 & 10 & 75 \\
\hline BP & 7 & 5 & 2 & 3 & - & 1 & 2 & - & 25 \\
\hline
\end{tabular}

$\mathrm{n}=10$ students

Source: Research Data, 2018

\section{Information:}

P2 = Question 2 = How could you find the Rector Build-

ing?

$\mathrm{BT} \quad=$ inquiry

$\mathrm{BP} \quad=$ Read Instructions

$\mathrm{n} \quad=$ Total samples of each faculty

$\mathrm{T}=$ Faculty of Engineering

$\mathrm{E} \quad=$ Faculty of Economics

IS $=$ Faculty of Social Science

BS = Faculty of Language and Art

IP = Faculty of Science

MP = Faculty of Mathematics and Science

$\mathrm{K}=$ Faculty of Sport Science

Gs = Graduate School

$\mathrm{B} \quad=$ Weight $=($ Real Score: Score Ideal $) * 100 \%$

Table 3: Student Perception in Determining the Route (P3)

\begin{tabular}{|c|c|c|c|c|c|c|c|c|c|}
\hline \multicolumn{10}{|c|}{ Selection of Reasons } \\
\hline P3 & T & E & IS & BS & IP & MP & K & Gs & B \\
\hline D & 2 & 6 & 5 & 6 & 3 & 5 & 7 & 10 & 55 \\
\hline KN & 1 & 1 & - & 3 & 3 & - & 1 & - & 11.25 \\
\hline DK & 7 & 3 & 5 & 1 & 4 & 5 & 2 & - & 33.75 \\
\hline
\end{tabular}

$\mathrm{n}=10$ students

Source: Research Data, 2018

Information:

P3 = Question 3 = factor is what causes you choose this route?

$\mathrm{D}=$ Shortest distance

$\mathrm{KN} \quad=$ Factor Leisure
DK $=$ Close and Cozy

$\mathrm{n} \quad=$ Number of samples of each faculty

$\mathrm{T} \quad=$ Faculty of Engineering

$\mathrm{E} \quad=$ Faculty of Economics

IS $\quad=$ Faculty of Social Science

BS = Faculty of Language and Art

IP = Faculty of Science

MP = Faculty of Mathematics and Science

$\mathrm{K} \quad=$ Faculty of Sport Science

Gs = Graduate School

B $\quad=$ Weight $=($ Real Score: Score Ideal $) * 100 \%$

Table 4: Student Perception in Determining the Route (P4)

\begin{tabular}{|c|c|c|c|c|c|c|c|c|c|}
\hline \multicolumn{10}{|c|}{ Selection of Reasons } \\
\hline P4 & T & E & IS & BS & IP & MP & K & Gs & B \\
\hline Y & 7 & 2 & 6 & 8 & 10 & 9 & 5 & 10 & 71.25 \\
\hline N & 3 & 8 & 4 & 2 & - & 1 & 5 & - & 28.75 \\
\hline
\end{tabular}

$\mathrm{n}=10$ students

Source: Research Data, 2018

Information:

P4 = Question $4=$ Do you always use the sidewalk to walk to get to the Rector Building?

$\mathrm{Y} \quad=$ Yes

$\mathrm{N} \quad=\mathrm{No}$

$\mathrm{n} \quad=$ Number of samples of each faculty

$\mathrm{T} \quad=$ Faculty of Engineering

$\mathrm{E} \quad=$ Faculty of Economics

IS $\quad=$ Faculty of Social Science

BS = Faculty of Language and Art

IP = Faculty of Science

MP = Faculty of Mathematics and Science

$\mathrm{K} \quad=$ Faculty of Sport Science

Gs = Graduate School

B $\quad=$ Weight $=($ Real Score: Score Ideal $) * 100 \%$

Data shows that $27.5 \%$ of the new registered students from YSU encountered difficulties in finding location to the Rectorate Building. These students are those studied at the Faculty which is located quite far with the Rector Building. They are Faculty of Engineering, Faculty of Economics, Faculty of Social Sciences, and the Faculty of Sport Sciences. Conversely, students who do not have difficulty comes from the faculty that is located near from the Rectorate Building. It was highlighted in the interview data that the difficulties caused by the absence of a map of YSU at strategic points of the pedestrian, in any cases where the faculty is far, the condition of roads and buildings that do not characterize (landmark) becomes the major part of difficulties to facilitate those pedestrian considering in finding the location.

New registered students from each faculty could can find the Rector Building by asking friends, relatives and seniors rather than read the sign or signs name on every street corner of the campus. $75 \%$ of students obtain location information the Rectorate Building by asked other peoples, while $25 \%$ were mainly referring to signpost provided at every corner of the campus. The lack of pedestrians using the functions of signpost is due to the pavement design, and the ergonomic are not precisely covered by a roof for the purpose of sidewalk. So if going to read these signs, pedestrians had to get off the sidewalk in advance and must share the road with motor vehicles.

Based on research data obtained, most of the new students choose closest distance route. It is shown by the data as much as $55 \%$ of students, while the comfort factor as much as $11.25 \%$ and both as much as $33.75 \%$.

$71.25 \%$ of the new registered students use the sidewalk to go to Rectorate Building The main consideration of sidewalks are not always being used because of the wide pedestrian walkways that does not allow pedestrian to run into the two opposite directions, on the sidewalk of YSU south (Colombo Road). Major activities of trade done on the sidewalks, forcing pedestrians to cross the road for vehicles. The layout of the faculty too affects the use of sidewalks among by pedestrians. YSU is surrounded with major 
construction by the roadside, hence, the pavement is increasing ly affected by the construction workers.

\subsubsection{Judging Student Perceptions of Gender}

By gender, there are differences in perception among students. The differences are seen from consideration in choosing a route used to reach the Rector Building from each faculty. Research data can be seen in the following table:

Table 5: Perception of Students Seen from Gender (P1)

\begin{tabular}{|c|c|c|c|c|}
\hline P1 & $\begin{array}{c}\mathrm{L} \\
\mathrm{n}=38\end{array}$ & $\begin{array}{c}\mathrm{P} \\
\mathrm{n}=42\end{array}$ & $\begin{array}{c}\mathrm{BL} \\
(\%)\end{array}$ & $\begin{array}{c}\mathrm{BP} \\
(\%)\end{array}$ \\
\hline $\mathrm{Y}$ & 17 & 16 & 44.7 & 38.1 \\
\hline $\mathrm{N}$ & 21 & 26 & 55.3 & 61.9 \\
\hline
\end{tabular}

Source: Research Data, 2018

\section{Information:}

P1 = Question 1 = Have you ever had trouble on the way to the Rector Building?

$\mathrm{Y} \quad=$ Yes

$\mathrm{N} \quad=$ No

$\mathrm{n}=$ The total number of samples of each gender

$\mathrm{BL} \quad=$ Weight for Men

BP = Weight Women

Formula Weight $=($ Real Score: Score Ideal $) * 100 \%$

Table 6. Perception of Students Seen from Gender (P2)

\begin{tabular}{|c|c|c|c|c|}
\hline P2 & $\begin{array}{c}\mathrm{L} \\
\mathrm{n}=38\end{array}$ & $\begin{array}{c}\mathrm{P} \\
\mathrm{n}=42\end{array}$ & $\begin{array}{c}\mathrm{BL} \\
(\%)\end{array}$ & $\begin{array}{c}\mathrm{BP} \\
(\%)\end{array}$ \\
\hline BT & 23 & 31 & 60.5 & 73.8 \\
\hline MP & 15 & 11 & 39.5 & 26.2 \\
\hline
\end{tabular}

Source: Research Data, 2018

\section{Information:}

P2 = Question 2 = How could you find the Rector Build-

ing?

$\mathrm{BT}=$ inquiry

MP = Reading Tips

$\mathrm{n}=$ The total number of samples of each gender

$\mathrm{BL} \quad=$ Weight for Men

$\mathrm{BP} \quad=$ Weight Women

Formula Weight $=($ Real Score: Score Ideal $) * 100 \%$

Table 7: Perception of Students Seen from Gender (P3)

\begin{tabular}{|c|c|c|c|c|}
\hline P3 & $\begin{array}{c}\mathrm{L} \\
\mathrm{n}=38\end{array}$ & $\begin{array}{c}\mathrm{P} \\
\mathrm{n}=42\end{array}$ & $\begin{array}{c}\mathrm{BL} \\
(\%)\end{array}$ & $\begin{array}{c}\mathrm{BP} \\
(\%)\end{array}$ \\
\hline $\mathrm{D}$ & 12 & 25 & 31.5 & 59.5 \\
\hline $\mathrm{KN}$ & 8 & 3 & 21.1 & 7.2 \\
\hline $\mathrm{DK}$ & 18 & 14 & 47.4 & 33.3 \\
\hline
\end{tabular}

Source: Research Data, 2018

Information:

P3 = Question 3 = factor is what causes you choose this

route?

BT = inquiry

MP = Reading Tips

$\mathrm{n} \quad=$ The total number of samples of each gender

$\mathrm{BL} \quad=$ Weight for Men

$\mathrm{BP} \quad=$ Weight Women

Formula Weight $=($ Real Score: Score Ideal $) * 100 \%$

Table 8: Perception of Students Seen from Gender (P4)

\begin{tabular}{|c|c|c|c|c|}
\hline P1 & $\begin{array}{c}\mathrm{L} \\
\mathrm{n}=38\end{array}$ & $\begin{array}{c}\mathrm{P} \\
\mathrm{n}=42\end{array}$ & $\begin{array}{c}\text { BL } \\
(\%)\end{array}$ & $\begin{array}{c}\text { BP } \\
(\%)\end{array}$ \\
\hline $\mathrm{Y}$ & 20 & 29 & 52.6 & 69.1 \\
\hline $\mathrm{N}$ & 18 & 13 & 47.4 & 30.9 \\
\hline
\end{tabular}

Source: Research Data, 2018

\section{Information:}

P4 = Question $4=$ Do you always use the sidewalk to walk to get to the Rector Building?

$$
\begin{array}{ll}
\mathrm{Y} & =\text { Yes } \\
\mathrm{N} & =\text { No } \\
\mathrm{n} & =\text { The total number of samples of each gender } \\
\mathrm{BL} & =\text { Weight for Men } \\
\mathrm{BP} & =\text { Weight Women }
\end{array}
$$

Formula Weight $=($ Real Score: Score Ideal $) * 100 \%$

There is an interesting result from these data. Grouping data by gender aimed to find behaviors / practices carried out by male and female students within walking distance of the Rector Building. The results obtained are:

\subsubsection{Difficulty Go to the Rector Building}

Each student is having trouble walking to find the Rectorate Building. By gender, male students face more difficulty when walking to find the Rector Building. A total number of $44.7 \%$ college students find it difficult, and only $38.1 \%$ female students experiencing difficulties. The figure shows that female is more conscientious and concerned about the environment around campus than male.

\subsubsection{Wayfinding Rectorate Building}

Judging from gender, there are different habits of students in finding Rector Building. Male and female students prefer to ask than to read the signpost. This method is simpler than when walking interspersed to study the existing signposts. Although not many students who use the map as a guide to get to the Rector Building. Data indicated that $60.5 \%$ and $73.8 \%$ of students prefer asking friends, relatives and seniors to find a ways of information to Rector Building. While, $39.5 \%$ students who use the facilities of using signpost to Rector Building than $26.2 \%$ of female students. This shows that the figure means that the student prefers to ask than the student read signpost.

\subsubsection{Reason for Choosing Route}

Based on the research that has been done, there are various routes that used by the student to walk to Rector Building. Many factors cause pedestrians to choose the route, including the convenience factor and the distances are considered more closely. It can be concluded that the student prefers shorter than the route that comfortable yet distant. A total number of $59.5 \%$ female students and $31.5 \%$ of students prefer the route with the shortest distance. While, selecting routes based on comfort as much as $21.1 \%$ and $7.2 \%$ student based leisure factor. As reasonable as the comfort factor and the shortest distance is $47.4 \%$ of students and $33.3 \%$ female students. These factors are influenced by the physical condition of the students.

\subsubsection{The Utilization of Sidewalks}

Availability pavement is expected to improve road users for pedestrians. So that students will be trained to live healthy, suave, and exchanged greetings when meeting with other pedestrians. Sidewalks in YSU campus have broadly been met properly procured. Based on the results of research conducted on the data obtained on the sidewalk as much as $52.6 \%$ of students and $69.2 \%$ female students. While, pedestrians do not use sidewalks facilities $47.4 \% 30.9 \%$ students and student. Of these say that students prefer not always use the sidewalk to get to the Rector Building. The cause of the students does not always use the sidewalk is a pavement width of less facilitated two pedestrians who cross paths, the resulting route farther away from the destination location, and the physical quality of the pavement which was considered necessary to do repairs. While, the student prefers always use the sidewalk because of safety and comfort. The safety factor is if the student uses the road for a vehicle then they must share the road with vehicles and feared an accident arise. Whereas the convenience factor is a sidewalk that is 
friendly to the existing weather changes. The safety factor is if the student uses the road for a vehicle then they must share the road with vehicles and feared an accident arise. Whereas the convenience factor is a sidewalk that is friendly to the existing weather changes. The safety factor is if the student uses the road for a vehicle then they must share the road with vehicles and feared an accident arise. Whereas the convenience factor is a sidewalk that is friendly to the existing weather changes.

\subsubsection{Walking Movement Patterns}

Based on the results of research and data processing, data about the picture pedestrian movement patterns of the most frequently performed of the Faculty of heading YSU Rector Building. There are 8 faculties which became the starting point of movement. Here presented an overview of the movement patterns YSU students as pedestrians on the way to the Rector Building:

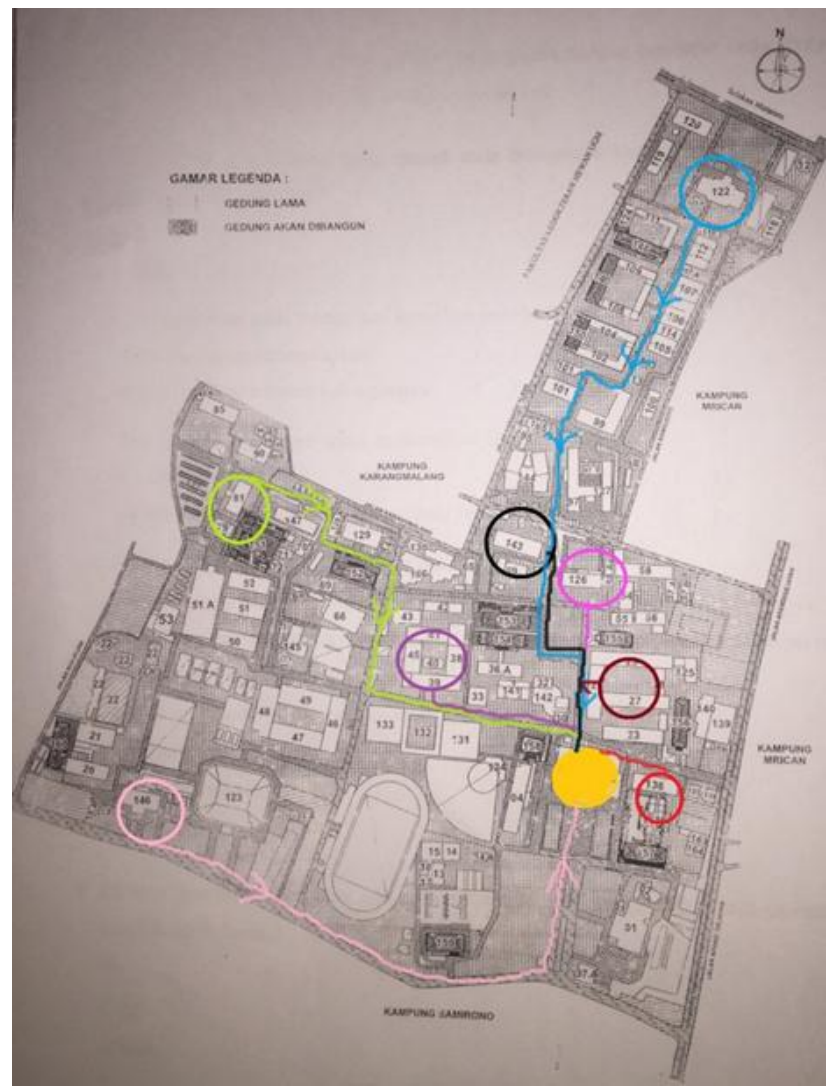

Fig. 2: Walking Movement Patterns

\section{Conclusion}

Pedestrians have difficulties in finding the location of the Rectorate Building. Pavement design that has not been able to safely facilitate to pedestrians resulting in them prefer not to use nearby sidewalk. Such conditions can affect the safety of pedestrians, because the roads are located on campus is not only used by pedestrians, but users of other vehicles. Neighboring environment with other campuses and population causing road traffic conditions quite crowded, so as to realize green campus sidewalks should be redesigned to fit the needs of pedestrian users. The access road between faculties are not only intended for vehicle users, so that convenience for pedestrians will be disrupted. The reason is what makes the inadequate number of pedestrians (students) at the YSU. Pavement design improvements should be done, in order to increase the number of pedestrians as a form of realizing a green campus.

This study was limited to finding pedestrian routes used, in order to obtain the design flow of sidewalks should be built. Great expectations, this research can be continued by other researchers who deigned to identify the needs of the pavement elements at the YSU.

\section{References}

[1] Passini, R. (1984). Wayfinding in architecture, environmental design series. Van Nostrand Reinhold Company.

[2] Marquardt, G. (2011). Wayfinding for people with dementia: A review of the role of architectural design. HERD: Health Environments Research and Design Journal, 4(2), 75-90

[3] Andresen, E., Haensel, D., Chraibi, M., \& Seyfried, A. (2016). Wayfinding and cognitive maps for pedestrian models. In Traffic and Granular Flow'15. Cham: Springer, pp. 249-256.

[4] Li, R., \& Klippel, A. (2016). Wayfinding behaviors in complex buildings: The impact of environmental legibility and familiarity. Environment and Behavior, 48(3), 482-510.

[5] Laurìa, A., Secchi, S., \& Vessella, L. (2018). Visual wayfinding for partially sighted pedestrians-The use of luminance contrast in outdoor pavings. Lighting Research and Technology, 2018, 1-19.

[6] Ansusanto, J., Priyanto, S., Munawar, A., \& Wibisono, B. H. (2013). Karakteristik pola perjalanan di perkotaan (Studi kasus kota Yogyakarta). Proceedings of the 16th FSTPT International Symposium, pp. 1-10.

[7] Talav, G., Gustavsen, A., \& Taue, J. V. (2005). Experimental confirmation on the theoretical model for velocity profile in a rectangular wind tunnel. Proceedings of the 8th Symposium on Building Physics in the Nordic Countries, pp. 16-18.

[8] Mohammed, S., Ferzandi, L., \& Hamilton, K. (2010). Metaphor no more: A 15-year review of the team mental model construct. Journal of Management, 36(4), 876-910.

[9] Sanjaya, R., \& Mudiyono, R. (2017). Analisis fungsi dan kenyamanan jalur pedestrian kawasan di kota pangkalan bun. Proceedings of the Seminar Nasional Inovasi Dalam Pengembangan SmartCity, pp. 108-122.

[10] Yunizar, D. K. (2017). Studi ergonomi pada aksesibilitas difable puskesmas depok i sleman: Studi kasus puskemas depok i sleman Jurnal Arsitektur Komposisi, 11(1), 21-32.

[11] Keputusan Direktur Jenderal Perhubungan Darat nomor: SK.43/AJ 007/DRJD/97 tahun 1997 tentang perekayasaan fasilitas pejalan kaki di wilayah kota.

[12] Yuan, Z., Jia, H., Liao, M., Zhang, L., Feng, Y., \& Tian, G. (2017). Simulation model of self-organizing pedestrian movement considering following behavior. Frontiers of Information Technology and Electronic Engineering, 18(8), 1142-1150.

[13] Roess, R. P., Prassas, E. S., \& McShane, W. R. (2004). Traffic engineering. Printice-Hall.

[14] Muchtar, C. (2010). Identifikasi tingkat kenyamanan pejalan kaki: studi kasus jalan kedoya raya-arjuna selatan. Planesa, 1(2), 153-159.

[15] Mashuri, M., \& Ikbal, M. (2011). Studi karakteristik pejalan kaki dan pemilihan jenis fasilitas penyeberangan pejalan kaki di kota palu (Studi kasus: J1. emmi saelan depan mal tatura kota palu). Jurnal Rekayasa dan Manajemen Transportasi, 1(2), 69-79.

[16] Mirzayi, C. (2010). Health and place: Special commodities in new urban development. Cities in the 21st Century, 2(1), 1-29.

[17] Sung, H., Go, D., Choi, C.-g, Cheon, S., \& Park, S. (2015). Effects of street-level physical environment and zoning on walking activity in Seoul, Korea. Land Use Policy, 49, 152-160.

[18] Monteiro, F. B., \& Campos, V. B., (2012). A proposal of indicators for evaluation of the urban space for pedestrians and cyclists in access to mass transit station. Procedia-Social and Behavioral Sciences, 54, 637-645.

[19] Saito, Y., Oguma, Y., Inoue, S., Tanaka, A., \& Kobori, Y., (2013). Environmental and individual correlates of various types of physical activity among community-dwelling middle-aged and elderly Japanese. International Journal of Environmental Research and Public Health, 10(5), 2028-2042.

[20] Taboada, L. M. (2015). Non-residential pedestrian access to transit systems: A GIS modeling application. University of Tennessee.

[21] Wicramasinghe, V., \& Dissanayake, S. (2017). Evaluation of pedestrians' sidewalk behavior in developing countries. Transportation Research Procedia, 25, 4068-4078.

[22] Badland, H., \& Schofield, G. (2005). Transport, urban design, and physical activity: An evidence-based update. Transportation Research Part D: Transport and Environment, 10(3), 177-196.

[23] De Cambra, P. J. M. (2012). Pedestrian accessibility and attractiveness indicators for walkability assessment. 
https://fenix.tecnico.ulisboa.pt/downloadFile/395144992898/Diss ertacao.pdf.

[24] Giles-Corti, B., \& Donovan, R. J. (2002). Socioeconomic status differences in recreational physical activity levels and real and perceived access to a supportive physical environment. Preventive Medicine, 35(6), 601-611.

[25] Giles-Corti, B., \& Donovan, R. J. (2003). Relative influences of individual, social environmental, and physical environmental correlates of walking. American Journal of Public Health, 93(9), 1583-1589.

[26] Guo, Z. (2009). Does the pedestrian environment affect the utility of walking? A case of path choice in downtown Boston. Transportation Research Part D: Transport and Environment, 14(5), 343-352.

[27] Abu-Ghazzeh, T. M. (1996). Movement and wayfinding in the King Saud University built environment: A look at freshman orientation and environmental information. Journal of Environmental Psychology, 16(4), 303-318.

[28] Sugiyono. (2017). Metode penelitian pendidikan pendekatan kuantitatif kualitatif, dan RnD. Alfabeta.

[29] Bogdan, R. C., \& Biklen, S. K. (1990). Riset kualitatif untuk pendidikan. Dekdikbud. 